\title{
Muş ilindeki besi işletmelerinde irk tercihi ve etkileyen faktörler
}

\section{Breed preference and factors affecting fattening enterprises in Muş province}

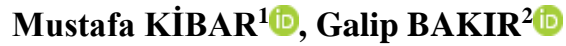 \\ ${ }^{1}$ Selçuk Üniversitesi, Ziraat Fakültesi, Zootekni Bölümü, 42130, Konya \\ ${ }^{2}$ Kahramanmaraş Üniversitesi, Ziraat Fakültesi, Zootekni Bölümü, 46000, Kahramanmaraş \\ Sorumlu yazar (Corresponding author): M. Kibar, e-posta (e-mail): mustafa.kibar@selcuk.edu.tr \\ Yazar(lar) e-posta (Author e-mail): galipbakir@hotmail.com
}

\section{MAKALE BİLGİSİ}

Alınıs tarihi 30 Haziran 2020

Düzeltilme tarihi 31 Aralık 2020

Kabul tarihi 07 Ocak 2021

\section{Anahtar Kelimeler:}

Besi işletmeleri

Irk tercihi

Etkileyen faktörler

Muş ili

\section{ÖZ}

$\mathrm{Bu}$ araştırma, besi işletmelerinin ırk tercihleri ve işletmecilerin ırk tercihinde etkili faktörlerin belirlenmesi amacıyla yapılmıştır. Bu amaçla, Muş ili ve 5 ilçesinde 368 işletmede anket çalışması yapılmıştır. Elde edilen veriler SPSS paket programında analiz edilerek, çapraz tablolar olușturulmuș ve faktörlerin etkileri ki-kare testi ile belirlenmiștir. İșletmecilerin urk tercihleri işletmelerin mevki, hayvan sayısı, işletmecilerin deneyimi, eğitim durumları, besicilikten memnuniyet, besiciliği sürdürme ve sürdürme nedenleri, besicilik yapma sebepleri ve uyguladıkları besi programına göre farklılık göstermiştir. İşletmelerde besicilik yerli, melez ve kültür ırkları kullanılarak hem tek ırk halinde hem de besi materyalinin ucuz olması, pazar da ne varsa ya da ahırın boș kalmaması gibi nedenlerle iki veya üç ırkın yer aldı̆̆ı karma olarak yapılmaktadır. İşletmeciler genel olarak bir sonraki ırk olarak melez genotip ağırlıklı olmak üzere, melez ve kültür ırkını tercih etmektedirler. Ancak, yetiştirdikleri ırklardan elde ettikleri tecrübe, mevki, işletmecinin yaşı ve hayvan sayısı gibi faktörlere göre bağlı olarak değişim göstermekle birlikte, yerli urk yetiştirenler melez genotipi, melez genotip yetiştirenler ise hem melez hem de kültür ırkını tercih etmişlerdir. Sonuç olarak, işletmecilerin tecrübelerinin artması ve besicilikten gelir sağladıkları sürece hem daha iyi ırkı tercih ettikleri hem de işletmelerini geliştirme yönünde gayret gösterdikleri belirlenmiştir.

\section{ARTICLE INFO}

Received 30 June 2020

Received in revised form 31 December 2020

Accepted 07 January 2021

\section{Keywords:}

Fattening farms

Breed preference

Affecting factors

Muş province

\section{ABSTRACT}

This study was conducted to determine the effects of factors on the breed preferences of fattening enterprises and the breed preferences of farmers. For this purpose, survey work was carried out in 368 enterprises in the province of Muş and its districts. The data obtained were analyzed in SPSS package program, cross tables were created and the effects of the factors were determined by Chi-square test. The breed preferences of the farmers differed according to the location of the enterprises, the number of animals, the experience of the farmers, their training status, satisfaction with feeding, the reasons for continuing and maintaining the business, the reasons for feeding and the fattening program they applied. In the enterprises, fattening is carried out by using domestic, cross and cultural breeds both with one breed and with two or three breeds mixed for several reasons such as being cheap fattening material, whatever is available in market or not to keep the barn on occupied. In general, the farmers prefer the cross and cultural breeds, with the emphasis being on the crossbreds as the next breed. However, their own experience based on the breeds they raised change depending on factors such as, location, age of farmer and the number of animals, however, the farmers previously used breed, native breeds wanted to study with crossbreds whereas the farmers previously dealt crossbreds wanted to study with both cross and culture breeds. As a result, it was determined that as farmers improve their experience and make money from fattening generate income they both prefer to work with better breeds and strive to develop their businesses. 


\section{Giriş}

Tarımsal üretimde genetik olarak üstün özelliklere sahip materyallerle çalışmak karlı bir işletmenin en temel faktörüdür. Hayvancılık da tarımsal bir faaliyet olup, gerek süt gerekse et üretimi için verimi yüksek irklarla çalışmak gerekmektedir. İşletmecilerin işletmelerinin sürdürülebilirliğini sağlamak için karlı bir işletme yönetimi sağlaması zorunludur. İşletmelerin karlılığında birçok faktör yanında yetiştirilen ırkında önemli bir yeri vardır. $\mathrm{Bu}$ nedenle işletmeciler sürdürülebilirliği sağlamak için rrk tercihine önem vermektedir. İşletmecilerin 1 rk tercihleri üzerine işletmenin mevki, işletmede bulunan hayvan sayısı ve 1rkı, işletmecilerin eğitim durumu ve deneyimleri vb. gibi bazı faktörlerin etki ettiği bildirilmektedir (Bakır ve Kibar 2019). Sı̆̆ırcılık işletmelerinde yetiştiricilerin ırk tercihinin belirlenmesine yönelik sınırlı sayıda çalışma bulunmaktadır (Bakır 2002; Tugay 2003; Tugay ve Bakır 2006; Han ve Bakır 2009; Şeker ve ark. 2012; Bakır ve Kibar 2019; Bakır ve Ören 2020). Diyarbakır ili Ergani ilçesinde yapılan bir çalı̧̧mada işletmecilerin eğitim seviyesi arttıkça melez genotipi daha çok tercih ettikleri bildirilmiştir. Ayrıca besleme şartları ile hastalıklara ve uzun yürümeye dayanıklı olmasından dolayı yerli irk tercih eden işletmecilerinde olduğu belirtilmiştir (Han ve Bakır 2009). Tugay ve Bakır (2006) Giresun ilinde sı̆ğırcılık işletmelerinde kültür ve melez genotiplerin daha çok tercih edildiğini ve kültür ırklarından Siyah Alaca, Esmer ve Jersey ırklarının daha çok tercih edildiğini bildirmişlerdir. Araştırıcılar bu ırkların tercih edilmesinde verimin, 1rkların bakımbeslemelerinin kolay olmasının ve pazar şartlarının etkili olduğunu belirtmişlerdir. Güler ve ark. (2016) Erzurum ili Hınıs ilçesinde daha çok melez (\%77.2) genotiplerin tercih edildiğini ve bu durumun alışkanlıktan kaynaklı olduğunu bildirmişlerdir. Yılmaz (2005) tarafından Erzurum ilinde yapılan araştırmada, sığır yetiştiricilerinin \%43.2'sinin Esmer ve \%23.5'inin Simental ırkını tercih ettikleri tespit edilmiştir. Bakır ve Kibar (2019) Muş ilindeki süt işletmelerinde yaptıkları araştırmada, işletmelerde yetiştirilen sığırların \%4'ünün yerli, \%26.9'unun melez ve \%69.1'inin kültür rrk1 olduğunu bildirmişlerdir. Araştırıcılar kültür ırkı içerisinde de en yüksek tercih edilen ırkın \%74.9 oranıyla Simental ırkının olduğunu ve bunu \%15 oranıyla Esmer ırkının izlediğini tespit etmişlerdir. Bakır ve Ören (2020) Siirt ili süt sığırı işletmelerinde yaptıkları araştırmada, işletmelerin rk tercihlerinin melez $(\% 40.8)$, yerli $(\% 28.8)$ ve kültür $(\% 12.8)$ şeklinde olduğunu bildirmişlerdir. Bu çalışma, Muş ilindeki besi işletmelerinin ırk tercihlerinin ve işletmecilerin irk tercihinde etkili olan faktörlerin belirlenmesi amacıyla yapılmıştır.

\section{Materyal ve Metot}

Araştırma materyalini, Muş il Merkezi ile Malazgirt, Bulanık, Hasköy, Korkut ve Varto olmak üzere 5 ilçeye bağlı köylerde besicilik yapan işletmelerde yüz yüze 2017 yılında yapılan anket çalışmasına ait veriler oluşturmuştur. Araştırmada büyükbaş hayvan varlığı bakımından ilçeleri temsil eden köyler, bölgede görev yapan Muş İl Tarım ve Orman Müdürlüğü elemanlarının görüşü alınarak belirlenmiştir. Araştırmanın amacına uygun olarak hazırlanmış anket formları kullanılarak, basit tesadüfi örnekleme yöntemiyle anket çalışması yürütülmüştür. İşletme sayısının belirlenmesinde Yamane (2006) örnek hacminin en az \%3'ünün veya Cochran (1977) \%10'unun alınmasının yeterli olacağı ilkesi dikkate alınmıştır. Bu bağlamda, Muş İl Tarım ve Orman Müdürlüğü kayıtlarından alınan toplam (2000) işletme sayısı dikkate alınarak, 368 (\%18.4) işletme belirlenmiştir. Anketlerin analizleri SPSS 25.0 paket programı kullanılarak çapraz tablolar oluşturulmuş (Yazıcıoğlu ve Erdoğan 2004) ve faktörlerin etkilerini belirlemek için ki-kare önemlilik testi (Düzgüneş ve ark. 1983) yapılmıştır.

\section{Bulgular ve Tartışma}

İşletmelerin $1 \mathrm{rk}$ tercihleri incelenirken, işletmelerin mevki, hayvan sayısı, işletmecilerin deneyimi, eğitim durumları, besicilikten memnuniyet, besiciliği sürdürme ve sürdürme nedenleri, besicilik yapma sebepleri ve uyguladıkları besi programları 1rk tercihini etkileyen faktörler olarak dikkate alınmış ve çapraz tablolar oluşturulmuştur. Ayrıca, işletmelerin mevcut 1rkları dikkate alınarak sonraki tercihleri arasında bir kıyaslama yapılması sağlanmıştır. İşletmelerde besicilik hem tek ırk kullanılarak hem de besi materyalinin ucuz olması, pazar da ne varsa ya da ahırın boş kalmaması nedenleriyle iki veya üç ırkın yer aldığı karma olarak da yapılmaktadır. Genel olarak, işletmelerin yarısında tek ırk ile besi yapılırken, diğer yarısında ise iki veya üç rrk birlikte karma olarak besi yapılmaktadır (Çizelge 1). Tek ırk ile besi yapan işletmelerdeki 1rk dağılımı melez (\%25.8), kültür (\%14.2) ve yerli (\%10.1) şeklinde iken, ırk tercihinde ise tek ırk dağılımı kültür (\%44.6), melez (\%35.1) ve yerli rrk (\%8.6) şeklinde bulunmuştur. Buna göre, işletmecilerin ırk tercihinde kültür ırkı öne çıkarken, bunu melez genotip izlemektedir. İşletmelerin mevcut yerli 1 rk oranlarına göre yerli irk tercihlerinde ciddi azalma görülmektedir. Ayrica, işletmecilerin \%88.3'ü işletmelerinde karma yerine tek 1rk tercihinde bulunması dikkat çekici bulunmuştur. Yetiştiricilerin çeşitli ırklar yerine verim yönünden memnun oldukları tek rrk ile çalışmak istedikleri düşünülmektedir. İşletmecilerin hem kültür ırkı tercihlerindeki artı̧̧ hem de işletmelerinde tek rrk yetiştirme eğiliminde olmaları önemli ve anlamlı bulunmuştur.

Daş ve ark. (2014) Bingöl ilinde sirasiyla melez, kültür ve yerli ırkların daha çok tercih edildiğini bildirmişlerdir. Yılmaz ve ark. (2003) Hatay ili projesiz süt sığırcılığı işletmelerinin \%43.3'ünün melez genotipleri tercih ettiğini belirtmişlerdir. Bakır (2002) ise Van ilindeki mevcut sığırların \%61.1'inin Sarı Alaca, \%33.5'inin Siyah Alaca ve \%5.4'ünün Esmer 1rk olduğunu ve işletmecilerin daha çok Simental (\%48.2) ve Esmer (\%26.3) 1rkları tercih ettiklerini tespit etmiştir. Şeker ve ark. (2012) Muş ilindeki sığır ırklarının \%46.9'unun yerli, $\% 37.2$ 'sinin melez ve \%15.9'unun ise kültür rrk1 olduğunu ve kültür ırk1 sığırların da \%70.3'ünün Esmer, \%17.2'sinin Simental ve \%12.5'inin Siyah Alaca 1rkından oluştuğunu bildirmişlerdir. Bakır ve Kibar (2019) Muş ilindeki süt işletmelerinde yetiştirilen sığırların \%4'ünün yerli, \%26.9'unun melez ve \%69.1'inin kültür rrk1 olduğunu bildirmişlerdir. Araştırıcılar kültür ırkı içerisinde de en yüksek oranla (\%74.9) Simental ırkının ve bunu \%15 oranla Esmer ırkının izlediğini tespit etmişlerdir. Bakır ve Ören (2020) Siirt ili süt sığırı işletmelerinde sırasıly melez (\%40.8), yerli (\%28.8) ve kültür (\%12.8) 1rklarının tercih edildiğini bildirmişlerdir.

İşletmelerde yetiştirilen mevcut $1 \mathrm{rk}$ ve 1 rk tercihi ile işletmelerin mevkiler arasında önemli $(p<0.01)$ farklılıklar bulunmuştur (Çizelge 1). Buna göre, il merkezinde melez ve melez+kültür 1rkları $(\% 46)$ diğer irklara oranla daha çok yetiştirilirken, yine melez ve kültür ırkları (\%46) diğer urklara oranla daha çok tercih edilmiştir. Malazgirt ilçesindeki işletmelerde yerli 1 rk $(\% 32.9)$ en fazla yetiştirilirken, melez+yerli+kültür ırkları $\% 44.7$ oranıyla çoklu 1rk olarak yetiştirilmektedir. Ancak, 1rk tercihinde yerli 1rk \%14.5 oranında yer alırken, bunu melez (\%34.8) ve kültür ırkları 
Çizelge 1. İşletmelerin ırk tercihinin mevkiye göre değişimi.

Table 1. The change in the race preference of the farms according to the location.

\begin{tabular}{|c|c|c|c|c|c|c|c|c|c|c|c|c|c|c|}
\hline \multirow[b]{2}{*}{ Mevki } & & \multicolumn{6}{|c|}{ Mevcut ırk** } & \multirow[b]{2}{*}{ Toplam } & \multicolumn{5}{|c|}{ Irk tercihi*** } & \multirow[b]{2}{*}{ Toplam } \\
\hline & & Yerli & Kültür & Melez & Melez+kültür & Melez+yerli & Melez+yerli+kültür & & Yerli & Melez & Kültür & Melez+yerli & Kültür+melez/yerli & \\
\hline \multirow{2}{*}{ Merkez } & Say1 & 3 & 5 & 29 & 17 & 3 & 3 & 60 & 3 & 23 & 23 & 4 & 4 & 57 \\
\hline & $\%$ & 5.0 & 8.3 & 48.3 & 28.3 & 5.0 & 5.0 & 100.0 & 5.3 & 40.4 & 40.4 & 7.0 & 7.0 & 100.0 \\
\hline \multirow{2}{*}{ Malazgirt } & Sayı & 25 & 14 & 2 & 0 & 1 & 34 & 76 & 10 & 24 & 31 & 2 & 2 & 69 \\
\hline & $\%$ & 32.9 & 18.4 & 2.6 & 0.0 & 1.3 & 44.7 & 100.0 & 14.5 & 34.8 & 44.9 & 2.9 & 2.9 & 100.0 \\
\hline \multirow{2}{*}{ Bulanık } & Say1 & 3 & 7 & 8 & 16 & 46 & 10 & 90 & 17 & 33 & 26 & 7 & 2 & 85 \\
\hline & $\%$ & 3.3 & 7.8 & 8.9 & 17.8 & 51.1 & 11.1 & 100.0 & 20.0 & 38.8 & 30.6 & 8.2 & 2.4 & 100.0 \\
\hline \multirow{2}{*}{ Hasköy } & Say1 & 1 & 2 & 4 & 4 & 1 & 1 & 13 & 0 & 7 & 5 & 0 & 1 & 13 \\
\hline & $\%$ & 7.7 & 15.4 & 30.8 & 30.8 & 7.7 & 7.7 & 100.0 & 0.0 & 53.8 & 38.5 & 0.0 & 7.7 & 100.0 \\
\hline \multirow{2}{*}{ Korkut } & Say1 & 0 & 24 & 9 & 34 & 1 & 2 & 70 & 0 & 20 & 42 & 0 & 8 & 70 \\
\hline & $\%$ & 0.0 & 34.3 & 12.9 & 48.6 & 1.4 & 2.9 & 100.0 & 0.0 & 28.6 & 60.0 & 0.0 & 11.4 & 100.0 \\
\hline \multirow{2}{*}{ Varto } & Say 1 & 5 & 0 & 42 & 1 & 8 & 0 & 56 & 0 & 16 & 29 & 6 & 5 & 56 \\
\hline & $\%$ & 8.9 & 0.0 & 75.0 & 1.8 & 14.3 & 0.0 & 100.0 & 0.0 & 28.6 & 51.8 & 10.7 & 8.9 & 100.0 \\
\hline \multirow{2}{*}{ Toplam } & Say1 & 37 & 52 & 94 & 72 & 60 & 50 & 365 & 30 & 123 & 156 & 19 & 22 & 350 \\
\hline & $\%$ & 10.1 & 14.2 & 25.8 & 19.7 & 16.4 & 13.7 & 100.0 & 8.6 & 35.1 & 44.6 & 5.4 & 6.3 & 100.0 \\
\hline
\end{tabular}


(\%44.9) izlemektedir. Bu ilçede ırk tercihinde yerli ırk yerine melez ve kültür ırkları rağbet görmüştür. Bulanık ilçesindeki işlemeler $\% 51.1$ oranında melez+yerli irk yetiştirirken, tek irk olarak melez ve kültür irklarının çok az oranda olması dikkat çekici bulunmuştur. Bu işletmeler irk tercihinde diğer ilçelerden farklı olarak \%20 oranında yerli 1rkı tercih etmeleri dikkat çekici bulunmuştur. Ayrıca, bu işletmeler \%30.6 oranında kültür ve $\% 38.8$ oranında melez genotipi tercih etmişlerdir. Hasköy ilçesindeki işletmelerin büyük çoğunluğu melez ve kültür ırk1 yetiştirirken, urk tercihleri $\% 53.8$ oranında melez genotip yönünde olmuştur. Bu ilçede işletmelerin melez genotip tercihi, melez genotipin yetersiz bakım ve besleme şartlarına kültür ırkından daha dayanıklı olması ve kültür ırkından daha ucuz olmasından kaynaklandığı düşünülmektedir. Korkut ilçesinde $\% 34.3$ oranında kültür ırk1 tek ırk olarak yetiştirilirken, bunu $\% 48.6$ oranıyla melez+kültür 1rkı izlemektedir. $\mathrm{Bu}$ işletmeler yetiştirdikleri kültür ırkından memnuniyetlerini $\% 60$ oranında kültür ırkını tercih ederek göstermişlerdir. Varto ilçesi yetiştirilen $1 \mathrm{rk}$ bakımından diğer ilçelerden farklılık göstermektedir. $\mathrm{Bu}$ işletmelerde $\% 75$ oranında tek irk şeklinde melez genotip yetiştirilmektedir. Bu işletmelerde 1 rk tercihinde melez genotipin oranının $\% 28.6$ düşmesi ve $\% 51.8$ oranında kültür ırkının tercih edilmesi anlamlı bulunmuştur. $\mathrm{Bu}$ işletmecilerin bölgenin coğrafik ve topoğrafik özelliklerine de bağlı olarak melez genotipin performansından memnun olmadıkları ya da kültür ırkını denemek istedikleri düşünülmektedir.

Bakır ve Kibar (2019) Muş ili süt işletmecilerinin ırk tercihi üzerine mevkinin önemli etkisinin olduğunu bildirmişlerdir $(\mathrm{p}<0.01)$. Araştırıcılar süt yetiştiricilerinin tüm ilçelerde farklı oranda olmasına rağmen çoktan aza doğru kültür, melez ve yerli 1rkların tercih edildiğini belirtmişlerdir. Bakır ve Ören (2020) mevkinin rrk tercihi üzerine etkili bir faktör olduğunu bildirmişlerdir $(\mathrm{p}<0.01)$. Araştırıcılar bazı ilçelerde kültür ırkının daha çok tercih edildiğini, bazı ilçelerde melez genotiplerin daha çok tercih edildiğini ve bazı ilçelerde ise yerli ırkların hiç tercih edilmediğini belirtmişlerdir. Kaylan ve ark. (2019) Iğdır ilinde yetiştiricilerin ırk tercihi üzerine mevkinin etkisinin önemsiz olduğunu ancak işletmecilerin çoğunluğunun (\%53.7) Simental ve Esmer 1rkları tercih ettiklerini belirtmişlerdir. Tugay ve Bakır (2006) Giresun ilinde sahil kesimdeki işletmelerin az da olsa yerli 1 rkı tercih etmelerine rağmen orta ve yüksek kesimdeki işletmelerin yerli 1 rkı hiç tercih etmediklerini belirtmişlerdir. Mevcut çalışma ile Bakır ve Kibar (2019), Bakır ve Ören (2020) ve Tugay ve Bakır (2006) uyum içerisinde iken Kaylan ve ark. (2019) farklılık göstermektedir.

İşletmelerdeki hayvan sayısı ile yetiştirilen ve tercih edilen ırk arasındaki ilişki önemli $(\mathrm{p}<0.01)$ bulunmuştur (Çizelge 2). Hayvan sayısı az olan işletmelerde tek 1rk olarak yetiştirilen kültür ırkı oranı \%40.6 iken, hayvan sayısı arttıkça bu oranın $\% 1.1$ 'e gerilemesi dikkat çekici bulunmuştur. Normal şartlarda işletmelerdeki hayvan sayısı arttıkça profesyonelleşmenin artması ve buna bağlı olarak da yetiştirilen kültür ırkı sayısının da artması beklenir. $\mathrm{Bu}$ gerilemenin hayvan sayısı arttıkça işletmecilerin tek ırk yerine kültür ırkının pahalı olması ve piyasada yeteri kadar bulunmaması gibi çeşitli nedenlerden dolayı birkaç 1 rkı birlikte yetiştirme politikasından kaynaklandığı düşünülmektedir. Örneğin hayvan sayısı 41 baş ve üzeri olan işletmelerde tek 1rk yetiştiren işletmelerin oranı $\% 26,1$ iken, birden fazla 1rk yetiştiren işletmelerin oran1 \%73.9 olarak bulunmuştur. Ancak, işletmecilerin 1rk tercihinde bu durum tek rrk yetiştirme lehine dönmüştür. Irk tercihinde işletmeciler, hayvan sayısına bağlı olarak tek irk olmak üzere bazen melez bazen ise kültür 1rk1 yönünde tercih de bulunmuştur. Ancak, hayvan sayısı 41 baş ve üzeri olan işletmelerin ırk tercihi \%63.6 oranında tek ırk olarak kültür ırk1 olmuştur. Bu sonuç üzerinden gidildiğinde, işletmelerde hayvan sayısı arttıkça tek olarak yetiştirilen kültür ırkı sayısı azalırken, 1rk tercihinde ise hayvan sayısı arttıkça işletmelerin tercih ettiği kültür ırkı sayısında ciddi artış tespit edilmiştir.

Bakır (2002) Van ili sığır işletmelerindeki hayvan sayısının yetiştiricilerin 1 rk tercihi üzerine etkili bir faktör olduğunu belirtmiştir. Araştırıcı 1-5 baş kültür ırkı bulunan işletmelerde, Siyah Alaca ırkı ile birlikte işletmecilerin \%46.7'sinin Simental, \%20.7'sinin Esmer ve \%15.6'sının ise Simental+Esmer urklarını tercih ettiklerini bildirmiştir. Simental rrkı ile birlikte işletmecilerin \%54'ünün Simental ve \%28.6'sının Esmer 1rk1 tercih ettiklerini tespit etmiştir. Esmer 1 rk1 ile birlikte ise işletmecilerin \%55'inin Esmer ve \%35'inin Simental 1rkı tercih ettikleri belirtmiştir. Bakır ve Han (2009) Diyarbakır ili Ergani ilçesindeki besi işletmelerinde daha çok melez genotipin (\%54.5) tercih edildiğini ve bunu \%30.3 oranla yerli irkların takip ettiğini bildirmişlerdir. Araştırıcılar elinde yerli rrk bulunan işletmecilerin yine yerli irkları ve elinde kültür ve melez bulunanların ise melez genotipi tercih ettiklerini belirtmişlerdir. Bakır ve Ören (2020) Siirt ilinde mevcut yetiştirilen ırkların yanında en çok kültür ırklarının (\%63.7) tercih edildiğini ve kültür ırkları içerisinde de Simental ırkının (\%72.4) daha çok tercih edildiğini bildirmişlerdir.

İşletmecilerin eğitim düzeyleri ile yetiştirdikleri rrklar arasında kimi zaman benzerlik kimi zamanda farklılıklar tespit edilmiştir (Çizelge 3). Okuryazar olmayan işletmeciler işletmelerinde \%36.4 oranında yerli 1 rk yetiştirirken, bu işletmecilerin hiç yerli 1 rk tercih etmemeleri dikkat çekici bulunmuştur. Okuryazar olmayan işletmecilerin sadece \%9.1 oranında kültür ırkını yetiştirmelerine rağmen, \%63.6 gibi yüksek oranda kültür ırkını tercih etmeleri de bir o kadar dikkat çekicidir. $\mathrm{Bu}$ işletmeciler her ne kadar eğitimleri olmasa da, hem yaşlı hem de yıllardır hayvancılık yaptıkları için iyi bir deneyime sahiptirler. Eğitim düzeyi ilkokul ve ortaokul olan işletmeciler ise melez+kültür ve melez+yerli şeklinde melez genotip ağırlıklı yetiştiricilik yapmaktadırlar. Bu işletmecilerin 1rk tercihleri ise, tek 1rk olmak üzere eğitim düzeyi ilkokul olanlarda melez, ortaokul olanlarda ise kültür 1rkı ağırlıklı olmuştur. Buradan eğitim düzeyi arttıkça kültür ırkını tercih eden işletmecilerin oranın da yükseldiği tespit edilmiştir. Eğitim düzeyi lise olan işletmeciler melez genotip ağırlıklı yetiştiricilik yaparken, tercih noktasında ise kültür ırkının oranında ciddi bir artış (\%55.3) olduğu görülmektedir. Sonuç olarak, melez genotip ağırlıklı yetiştiricilik yapan işletmecilerin, ancak bir sonraki 1rk tercihlerinde kültür 1rkını tercih ettikleri belirlenmiştir. Buna, eğitim düzeyi yükseldikçe işletmecilerin araştırma ve bilgi edinme cesaretlerinin artmasının yol açtığ düşünülmektedir.

Han ve Bakır (2009) Ergani'de eğitim düzeyi okuryazar olan ve olmayan işletmeciler tarafindan yerli urkların tercih edildiğini (\%48.5), eğitim seviyesi arttıkça melez genotiplerin daha çok tercih edildiğini belirtmişlerdir. Araştırıcılar sığır yetiştiricilerinin 1 rk seçimi üzerine eğitim düzeyinin etkili bir faktör olduğunu $(\mathrm{p}<0.05)$ bildirmişlerdir. Bakır ve Kibar (2019) Muş ili süt sığır işletmecilerinin ırk tercihi üzerinde eğitim seviyesinin önemli derecede etki ettiğini belirtmişlerdir $(\mathrm{p}<0.05)$. Araştırıcılar okuryazar olmayan işletmecilerin daha çok melez genotipi tercih ettiğini ve kültür ırkları içerisinde de Simental ırkının daha çok tercih edildiğini bildirmişlerdir. Ayrıca Muş ili süt işletmecileri tarafından eğitim seviyesi 
Çizelge 2. İşletmelerin ırk tercihinin hayvan sayısına göre değişimi.

Table 2. The change of the breed preference of the farms according to the number of animals.

\begin{tabular}{|c|c|c|c|c|c|c|c|c|c|c|c|c|c|c|}
\hline \multirow{2}{*}{\multicolumn{2}{|c|}{$\begin{array}{l}\text { Hayvan sayısı } \\
\text { (Adet) }\end{array}$}} & \multicolumn{6}{|c|}{ Mevcut 1rk** } & \multirow[b]{2}{*}{ Toplam } & \multicolumn{5}{|c|}{ Irk tercihi** } & \multirow[b]{2}{*}{ Toplam } \\
\hline & & Yerli & Kültür & Melez & Melez+kültür & Melez+yerli & Melez+yerli+kültür & & Yerli & Melez & Kültür & Melez+yerli & Kültür+melez/yerli & \\
\hline \multirow{2}{*}{$5<$} & Say1 & 15 & 39 & 22 & 17 & 3 & 0 & 96 & 7 & 41 & 43 & 3 & 1 & 95 \\
\hline & $\%$ & 15.6 & 40.6 & 22.9 & 17.7 & 3.1 & 0.0 & 100.0 & 7.4 & 43.2 & 45.3 & 3.2 & 1.1 & 100.0 \\
\hline \multirow{2}{*}{$6-20$} & Sayı & 18 & 7 & 33 & 24 & 22 & 5 & 109 & 13 & 40 & 32 & 7 & 7 & 99 \\
\hline & $\%$ & 16.5 & 6.4 & 30.3 & 22.0 & 20.2 & 4.6 & 100.0 & 13.1 & 40.4 & 32.3 & 7.1 & 7.1 & 100.0 \\
\hline \multirow{2}{*}{$21-40$} & Sayı & 2 & 4 & 19 & 10 & 22 & 14 & 71 & 10 & 22 & 24 & 6 & 4 & 66 \\
\hline & $\%$ & 2.8 & 5.6 & 26.8 & 14.1 & 31.0 & 19.7 & 100.0 & 15.2 & 33.3 & 36.4 & 9.1 & 6.1 & 100.0 \\
\hline \multirow{2}{*}{$41+$} & Sayı & 2 & 1 & 20 & 21 & 13 & 31 & 88 & 0 & 19 & 56 & 3 & 10 & 88 \\
\hline & $\%$ & 2.3 & 1.1 & 22.7 & 23.9 & 14.8 & 35.2 & 100.0 & 0.0 & 21.6 & 63.6 & 3.4 & 11.4 & 100.0 \\
\hline \multirow{2}{*}{ Toplam } & Say1 & 37 & 51 & 94 & 72 & 60 & 50 & 364 & 30 & 122 & 155 & 19 & 22 & 348 \\
\hline & $\%$ & 10.2 & 14.0 & 25.8 & 19.8 & 16.5 & 13.7 & 100.0 & 8.6 & 35.1 & 44.5 & 5.5 & 6.3 & 100.0 \\
\hline
\end{tabular}

Çizelge 3. İşletmelerin ırk tercihinin işletmecilerin eğitim durumlarına göre değişimi.

Table 3. The change of the race preference of the farms according to the educational status of the farmers.

\begin{tabular}{|c|c|c|c|c|c|c|c|c|c|c|c|c|c|c|}
\hline \multirow{2}{*}{\multicolumn{2}{|c|}{ Eğitim durumu }} & \multicolumn{6}{|c|}{ Mevcut ırk } & \multirow[b]{2}{*}{ Toplam } & \multicolumn{5}{|c|}{ Irk tercihi } & \multirow[b]{2}{*}{ Toplam } \\
\hline & & Yerli & Kültür & Melez & Melez+kültür & Melez+yerli & Melez+yerli+kültür & & Yerli & Melez & Kültür & Melez+yerli & Kültür+melez/yerli & \\
\hline \multirow{2}{*}{$\begin{array}{l}\text { Okuryazar } \\
\text { değil }\end{array}$} & $\begin{array}{l}\text { Sayı } \\
\end{array}$ & 4 & 1 & 2 & 2 & 1 & 1 & 11 & 0 & 4 & 7 & 0 & 0 & 11 \\
\hline & $\%$ & 36.4 & 9.1 & 18.2 & 18.2 & 9.1 & 9.1 & 100.0 & 0.0 & 36.4 & 63.6 & 0.0 & 0.0 & 100.0 \\
\hline \multirow{2}{*}{ İlkokul } & Sayı & 15 & 16 & 31 & 30 & 28 & 18 & 138 & 13 & 53 & 47 & 9 & 10 & 132 \\
\hline & $\%$ & 10.9 & 11.6 & 22.5 & 21.7 & 20.3 & 13.0 & 100.0 & 9.8 & 40.2 & 35.6 & 6.8 & 7.6 & 100.0 \\
\hline \multirow{2}{*}{ Ortaokul } & Sayı & 14 & 24 & 39 & 24 & 22 & 21 & 144 & 13 & 46 & 62 & 7 & 10 & 138 \\
\hline & $\%$ & 9.7 & 16.7 & 27.1 & 16.7 & 15.3 & 14.6 & 100.0 & 9.4 & 33.3 & 44.9 & 5.1 & 7.2 & 100.0 \\
\hline \multirow{2}{*}{ Lise } & Sayı & 2 & 6 & 17 & 11 & 6 & 8 & 50 & 3 & 14 & 26 & 2 & 2 & 47 \\
\hline & $\%$ & 4.0 & 12.0 & 34.0 & 22.0 & 12.0 & 16.0 & 100.0 & 6.4 & 29.8 & 55.3 & 4.3 & 4.3 & 100.0 \\
\hline \multirow{2}{*}{ Üniversite } & Sayı & 0 & 3 & 1 & 1 & 1 & 0 & 6 & 0 & 2 & 3 & 1 & 0 & 6 \\
\hline & $\%$ & 0.0 & 50.0 & 16.7 & 16.7 & 16.7 & 0.0 & 100.0 & 0.0 & 33.3 & 50.0 & 16.7 & 0.0 & 100.0 \\
\hline \multirow{2}{*}{ Toplam } & Sayı & 35 & 50 & 90 & 68 & 58 & 48 & 349 & 29 & 119 & 145 & 19 & 22 & 334 \\
\hline & $\%$ & 10.0 & 14.3 & 25.8 & 19.5 & 16.6 & 13.8 & 100.0 & 8.7 & 35.6 & 43.4 & 5.7 & 6.6 & 100.0 \\
\hline
\end{tabular}


arttıkça Simental yerine Esmer ırkın daha çok tercih edildiği bildirilmiştir. Bakır ve Ören (2020) Siirt ilinde eğitim seviyesi arttıkça yetiştirilen yerli ırkın azaldığı ve tercih edilen kültür ırkı oranının arttığını belirtmişlerdir.

İşletmecilerin deneyimi ile mevcut ırk dağılımı arasında önemli $(p<0.01)$ farklılıklar bulunmuştur (Çizelge 4$) .10$ yıldan az deneyime sahip işletmecilerin tek ark olarak yetiştirdikleri ırkların dağılım oranları melez ve kültür ırkların oranına benzer bulunmuştur. Ancak, irk tercihinde ise, kültür 1rk1 \%42.7 oranıla öne çıarken, bunu \%33.1 oranıla melez genotip izlemiştir. Buna karşın, deneyim süresi 31 yıl ve üzeri olan işletmecilerin 1 rk tercihlerinde ise $\% 40.3$ oranıla melez genotip öne çıkarken, bunu \%37.1 oranıyla kültür ırkı izlemiştir. Ayrıca, deneyim süresi arttıkça işletmecilerin melez genotip ve iki irk yetiştirme oranları da artmaktadır. Örneğin 21-30 y1l deneyime sahip işletmecilerin melez genotip yetiştirme oranı \%35.7'ye yükselmiştir. 31 ve üzeri deneyime sahip işletmelerde ise iki ırk yetiştirme oranları melez+kültür \%33.9 ve melez+yerli $\% 24.2$ olarak bulunmuştur. $\mathrm{Bu}$ işletmelerin melez genotip yanında yerli ve kültür ırkını da çeşitli nedenlerle yetiştirdikleri belirlenmiştir. Genel olarak işletmeciler, melez genotip ağırlıklı yetiştiricilik yaparken, özellikle deneyim arttıkça bir sonraki ırk tercihlerinde kültür ırkı öne çıkmaktadır.

Bakır ve Kibar (2019) tarafından Muş ilinde süt işletmecilerinin deneyim süresinin $1 \mathrm{rk}$ tercihi üzerine etkisi önemli bulunmuştur $(\mathrm{p}<0.01)$. Araştırıcılar deneyim süresi az olan işletmecilerin daha çok kültür ırkını tercih ettiklerini, deneyim süresi arttıkça melez ve yerli ırkı tercih edenlerin oranının artış gösterdiğini belirtmişlerdir. Han ve Bakır (2009) Ergani ilçesindeki besi işletmecilerinin deneyim süresinin $1 \mathrm{rk}$ tercihi üzerinde önemli derecede etki etmediğini bildirmişlerdir. Ancak araştırıcılar yine de farklı deneyim sürelerinde farklı eğilimlerin olduğunu belirtmesine rağmen tüm deneyim gruplarında melez genotiplerin daha çok tercih edildiğini bildirmişlerdir. Bakır ve Ören (2020) Siirt ilinde deneyim süresi arttıkça yetiştirilen yerli ve melez genotiplerin arttığını ve kültür ırkının azaldığını bildirmişlerdir.

İşletmelerde yetiştirilen mevcut rrk ile tercih edilen 1 rk arasında önemli $(\mathrm{p}<0.01)$ ilişki bulunmuştur (Çizelge 5). Buna göre, yerli rrk bulunan işletmecilerin \%29'unun yine yerli 1 rk1 tercih etmesi anlamlı bulunmuştur. $\mathrm{Bu}$ işletmelerde yerli irk tercihinden sonra en çok tercih edilen urklar melez ırk1 (\%32.3) olup ve bunu kültür ırkı (\%25.8) izlemiştir. İşletmelerin yerli 1rkı tercih etmeleri, işletmecilerin yaşı, yerli materyalin ucuz ve diğerlerine göre piyasada daha fazla bulunması ile işletmeler entansif ve ektansif olmaları gibi nedenlerden kaynaklandığ düşünülmektedir. Melez genotip yetiştiren işletmelerin yakın oranlarda melez ve kültür ırkını tercih etmișlerdir. $\mathrm{Bu}$ işletmelerin kültür ırkını tercih etmeleri işletmecilerin tecrübe ve imkânlarıyla alakalı olduğu düşünülmektedir. Kültür ırk1 yetiştiren işletmelerin $\% 52.9$ oranında yine kültür 1 rkını tercih ettikleri ve bunun yanında $\% 45.1$ oranında melez genotipi tercih etmeleri melez genotipin ucuz olması kültür ırkına göre piyasada daha fazla bulunması ve besi performansının tatmin edici olması ile açıklanabilmektedir. Kültür+melez genotipi birlikte yetiştiren işletmelerin $\% 60.9$ oranında kültür ırkını tercih etmeleri, ișletmecilerin her iki 1 rk1 birlikte yetiştirmelerinden dolayı bir kıyaslama imkânına sahip olmalarından kaynaklanabilir.

Bakır (2002) Van ilinde Siyah Alaca ırkı olan yetiştiricilerin \%9.8'inin Siyah Alaca, \%45.9'unun Simental, \%20.5'inin Esmer ve \%16.4'ünün Simental+Esmer ırkları tercih ettiklerini bildirmiştir. Araştırıcı Esmer ırkı olan yetiştiricilerin \%61.5'inin yine Esmer ırkı tercih ettiklerini belirtmiştir. İlde barınak ve bakım-besleme şartlarının yetersizliğinden dolayı Siyah Alaca yerine daha dayanıklı olan Esmer ırkın daha çok tercih edildiği bildirilmiștir. Bakır ve Ören (2020) Siirt ilinde mevcut 1rkın ırk tercihi üzerine etkili bir faktör olduğunu bildirmişlerdir $(\mathrm{p}<0.01)$. Araştırıcılar yerli ırk yetiştirenlerin \%43.7'sinin yine yerli 1rkları ve melez genotip yetiştirenlerin ise \%73.3'ünün kültür ırklarını ve \%25.7'sinin ise melez genotipleri tercih ettiklerini tespit etmişlerdir.

İşletmelerdeki besicilikten memnuniyet ile yetiştirilen ve tercih edilen rrk arasındaki ilişki önemli $(\mathrm{p}<0.05)$ bulunmuştur (Çizelge 6). Besicilikten memnun olan işletmeciler her irk ile besi yaparken, 1rk tercihinde ise kültür (\%48) ve melez (\%30.1) 1rk1 tercih etmişlerdir. Bunun aksine, besicilikten memnun olmayan işletmeciler hem işletmede yetiştirilen $1 \mathrm{rk}$ hem de tercih edilen ırk bakımından memnun olan işletmecilere göre farklılık göstermiştir. Buna göre, besicilikten memnun olmayan işletmeciler yetiştirilen kültür rkkı bakımından daha yüksek orana sahip iken, tercih edilen ırk bakımından daha düşük orana sahip olduğu tespit edilmiştir. Besicilikten memnun olmayan işletmecilerin kültür ırkından memnun olmadıkları ve bunun için daha çok melez genotipi tercih ettikleri belirlenmiştir. Diğer bir ifadeyle, işletmecilerin besicilikten memnun olmamalarında yetiştirdikleri kültür ırklarının etkisi olduğu düşünülmektedir.

Bakır ve Kibar (2019) Muş ili süt sığırcılığından memnun olan işletmecilerin \%65.8'inin kültür 1 rkını, \%30.2'sinin ise melez genotipi tercih ettiklerini ve kültür 1 rkı içerisinde de Simental ırkının (\%78.9) daha çok tercih edildiğini bildirmişlerdir.

Besiciliği sürdürme ve sürdürmeme bakımından sonuçlar memnuniyet sonuçlarıyla benzerlik göstermektedir (Çizelge 7). Besiciliği sürdürmek isteyen işletmeler her urk ile besi yaparken, ırk tercihinde ise $(\% 34.9)$ melez ve $(\% 44.5)$ kültür ırkını tercih etmişlerdir. Bunun aksine, besiciliği sürdürmek istemeyen işletmecilerin hem işletmede yetiştirilen hem de tercih edilen irk olan kültür ırkı bakımından daha yüksek oranlara sahip olduğu belirlenmiştir. Besiciliği sürdürme nedeni bakımından işletmelerin hem yetiştirdikleri 1rk hem de tercih ettikleri ırkların farklı olduğu belirlenmiştir (Çizelge 8). Buna göre, besiciliği karlı bulan işletmecilerin yarısından fazlası melez ve melez+kültür ırklarını yetiştirmelerine rağmen, \%58.8'inin sadece kültür ırkını tercih etmeleri anlamlı bulunmuştur. İşletmecilerin besicilikten kar ettikleri zaman hem kendilerini hem de işletmelerini geliştirerek karlılığı artırmanın çabasında oldukları belirlenmiştir. İşletmecilerin besi için melez genotip yerine kültür ırkını tercih etmeleri bunun göstergesi olarak düşünülebilir. Besiciliği sürdürme nedeni olarak elde edilen gelir bana yetiyor diyen işletmecilerin \%13.8 oranında yerli irk yetiştirmelerine rağmen, \%55.8 oranında sadece kültür ırkını tercih etmesi, işletmecilerin besiciliği sürdürme bakımından istekli olduklarını göstermektedir. Yine besiciliği sürdürme nedeni olarak başka iş olmadığını beyan eden işletmecilerin ağırlıklı olarak melez genotip yetiştirdikleri ve yine ağırlıklı olarak melez genotipini tercih etmeleri, melez genotipinin kültür ırkına göre hem ucuz hem de yetersiz bakım besleme şartlarına daha dayanıklı olmasından kaynaklandığı düşünülmektedir. Besiciliği sevdiği için sürdüren işletmeciler, her ırkı yetiştirerek besi yaptıkları ve tek ırk olarak da kültür ırkının yetiştirilme oranının \%6.7 olarak bulunması dikkat çekici bulunmuştur. Ancak, işletmecilerin urk tercihinde benzer oranlarda (\%46.7) melez ve kültür ırkını tercih etmişlerdir. Kültür ırkındaki bu artışın işletmecilerin deneyimi ve yetiştirdikleri kültür ırkının performansının iyi olmasından kaynaklandığı düşünülmektedir. 
Bakır ve Ören (2020) Siirt ilinde hayvancılığı sevdiği için yapan işletmelerin daha çok kültür 1rk1 ve kültür 1rkı içerisinden de Simental ırkını tercih ettiklerini belirtmişlerdir. Aynı araştırıcılar hayvancılığı karlı olduğu için sürdürmek isteyen işletmecilerin yine daha çok kültür ırkını ve kültür ırkları içerisinden de Simental ırkını tercih ettiklerini bildirmişlerdir. Araştırıcıların bulgularından Siirt ilinde besicilik için Simental ırkının karlı bir ırk olduğu ve bu nedenle de daha çok tercih edildiği anlaşılmaktadır.

Besiciliği yapma nedeni ile işletmelerdeki mevcut rrk $(\mathrm{p}<0.01)$ ile 1rk tercihi $(\mathrm{p}<0.05)$ arasında önemli ilişki bulunmuştur (Çizelge 9). Besiciliği baba mesleği olarak yapanlar ile başka işi olmadığından yapan işletmecilerin her ırk ile besicilik yaptığ melez ve kültür ırkını tercih ettikleri belirlenmiştir. Bunun yanında, besiciliği hem baba mesleği hem de başka işi olmadığ 1 için yapan işletmecilerin ise diğerlerinin aksine $\% 46.8$ oranında sadece melez genotip yetiştirdikleri belirlenmiştir. $\mathrm{Bu}$ işletmecilerin melez genotip yetiştirmesine rağmen, \%52.3 oranında kültür ırkını tercih etmeleri anlamlı bulunmuştur. $\mathrm{Bu}$ durum, yani melez genotip yetiştirirken, tercih noktasında melez genotiple birlikte daha çok kültür ırkını tercih etmeleri, işletmecilerin tecrübe ve imkânlarının iyileşmesiyle birlikte, kültür ırkını tercih ettikleri düşünülmektedir. Besiciliği başka işi olmadığı ve sevdiği için yapan işletmeciler hem yetiştirdiği irk hem de tercih ettiği ırk bakımından benzerlik göstermektedir. Her iki grup yetiştiriciler her irk ile besicilik yaparken, sadece melez ve kültür ırklarını tercih ettikleri belirlenmiştir.

Bakır ve Kibar (2019) Muş ili süt işletmecilerinin hayvancılık yapma sebebinin irk tercihi üzerine etkili bir faktör olduğunu ve genel olarak bu işi yapma sebebi ne olursa olsun kültür ırkının daha çok tercih edildiğini bildirmişlerdir.

Besi programı ile hem mevcut 1rk hem de 1rk tercihi arasında çok önemli $(\mathrm{p}<0.01)$ ilişki bulunmuştur (Çizelge 10). Buna göre, meraya dayalı besi programı uygulayan işletmecilerin, bölgenin mera şartlarına uygun olduğunu düşündükleri yerli rrklar ve melez genotip hayvanlarla besi yaptıkları belirlenmiştir. $\mathrm{Bu}$ işletmecilerin aynı düşüncelerle ırk tercihinde de yine melez genotipi tercih etmeleri anlaml bulunmuştur. Bilindiği gibi, yetersiz mera ve bakım besleme şartlarında melez genotipler kültür ırklarından daha iyi performans göstermektedir. Ahır besisi uygulayan işletmecilerin en düşük oranda kültür ırkı ve en yüksek oranda da yerli ırk yetiştirmeleri, kültür ırkının pahalı olmasından ve yerli ırkın ise hem ucuz hem de kolay bulunmasından kaynaklandığ düşünülmektedir. Ancak, bu işletmecilerin rrk tercihinde ise, melez ve kültür 1rkını tercih etmeleri bu 1rkların performanslarının iyi olmasından kaynaklanmaktadır. İşletmeciler hem tecrübelerinin artması hem de besicilikten kazanç sağladıkları sürece işletmelerini geliştirme yönünde gayret gösterdikleri belirlenmiştir.

\section{Sonuç}

İşletmelerde yerli, melez ve kültür ırkları ya tek ırk olarak ya da iki ve üç rrk birlikte yetiştirilmektedir. Genel olarak, işletmelerin yarısında tek ırk ile besi yapılırken, diğer yarısında ise iki veya üç ırk birlikte karma olarak besi yapılmaktadır. İşletmecilerin 1 rk tercihinde kültür 1 rkı öne çıkarken, bunu melez genotip izlemektedir. İşletmelerin irk tercihlerini işletmelerin mevki, hayvan sayısı, işletmecilerin deneyimi, eğitim durumları, besicilikten memnuniyet, besiciliği sürdürme ve sürdürme nedenleri besicilik yapma sebepleri ve uyguladıkları besi programları önemli şekilde etkilemiştir. İşletmelerde yetiştirilen yerli 1rk oranlarına göre, yerli irk tercihlerinde ciddi azalma görülmüştür. $\mathrm{Bu}$ durumun yerli rrkların verim düşüklüğünden kaynaklı olduğu düşünülmektedir. Islah çalışmaları ile verim bir nebze artırılsa da kültür ve melez genotiplerine yetişilmesinin çok zor olacağ düşünüldüğünden işletme şartlarına göre rrk tercihinin yapılmasının işletme verimliliği açısından daha önemli olduğu düşünülmektedir. Ayrıca, işletmecilerin tamamına yakını işletmelerinde bir kaç ırk karma yerine tek 1rk tercihinde bulunması dikkat çekici bulunmuştur. İşletmecilerin hem kültür ırkı tercihlerindeki artış hem de işletmelerinde tek ırk yetiştirme eğiliminde olmaları önemli ve anlamlı bulunmuştur. $\mathrm{Bu}$ durumun yetiştiricilerin sadece verime yönelik besicilik yapmasından kaynaklı olduğu düşünülmektedir. Yani işletmecilerin hangi irktan daha çok verim alıyorlarsa sadece onu tercih ettiği ve 1slaha yönelik bir çalışma yapmadıkları düşünülmektedir. İşletmecilerin tecrübelerinin artması ve çevre işletmelerden edindiği bilgiler ile beside performansı yetersiz olan yerli ırkları tercih etmediği, karma ırk yerine tek ırk ile besi yaptığ 1 ve kazanç sağladığ 1 takdirde hem kendini geliştirme hem de işletme şartlarını iyileştirme çabasında olduğu belirlenmiştir. 
Cizelge 4. İșletmelerin ırk tercihinin ișletmecilerin deneyimlerine göre değișimi.

Table 4. The change in the race preference of farms according to the experience of the farmers.

\begin{tabular}{|c|c|c|c|c|c|c|c|c|c|c|c|c|c|c|}
\hline \multirow[b]{2}{*}{ Deneyim (Y1l) } & & \multicolumn{6}{|c|}{ Mevcut Irk** } & \multicolumn{7}{|c|}{ Irk tercihi } \\
\hline & & Yerli & Kültür & Melez & Melez+kültür & Melez+yerli & Melez+yerli+kültür & Toplam & Yerli & Melez & Kültür & Melez+yerli & Kültür+melez/yerli & Toplam \\
\hline \multirow{2}{*}{$<10$} & Say1 & 22 & 28 & 29 & 14 & 19 & 18 & 130 & 13 & 41 & 53 & 10 & 7 & 124 \\
\hline & $\%$ & 16.9 & 21.5 & 22.3 & 10.8 & 14.6 & 13.8 & 100.0 & 10.5 & 33.1 & 42.7 & 8.1 & 5.6 & 100.0 \\
\hline \multirow{2}{*}{$11-20$} & Sayı & 3 & 13 & 27 & 22 & 14 & 18 & 97 & 6 & 37 & 43 & 4 & 3 & 93 \\
\hline & $\%$ & 3.1 & 13.4 & 27.8 & 22.7 & 14.4 & 18.6 & 100.0 & 6.5 & 39.8 & 46.2 & 4.3 & 3.2 & 100.0 \\
\hline $21-30$ & $\%$ & 8.6 & 10.0 & 35.7 & 21.4 & 15.7 & 8.6 & 100.0 & 6.1 & 27.3 & 53.0 & 4.5 & 9.1 & 100.0 \\
\hline \multirow{2}{*}{$31+$} & Say1 & 4 & 3 & 11 & 21 & 15 & 8 & 62 & 6 & 25 & 23 & 2 & 6 & 62 \\
\hline & $\%$ & 6.5 & 4.8 & 17.7 & 33.9 & 24.2 & 12.9 & 100.0 & 9.7 & 40.3 & 37.1 & 3.2 & 9.7 & 100.0 \\
\hline \multirow{2}{*}{ Toplam } & Say1 & 35 & 51 & 92 & 72 & 59 & 50 & 359 & 29 & 121 & 154 & 19 & 22 & 345 \\
\hline & $\%$ & 9.7 & 14.2 & 25.6 & 20.1 & 16.4 & 13.9 & 100.0 & 8.4 & 35.1 & 44.6 & 5.5 & 6.4 & 100.0 \\
\hline
\end{tabular}

**p $<0.01$

Çizelge 5. İşletmelerin ırk tercihinin yetiştirilen ırka göre değişimi.

Table 5. The change of the breed preference of the farms according to the breed.

\begin{tabular}{|c|c|c|c|c|c|c|c|}
\hline \multirow[b]{2}{*}{ Mevcut rrk } & & \multicolumn{5}{|c|}{ Irk tercihi** } & \multirow[b]{2}{*}{ Toplam } \\
\hline & & Yerli & Melez & Kültür & Yerli+melez & Kültür+melez/yerli & \\
\hline \multirow{2}{*}{ Yerli } & Say1 & 9 & 10 & 8 & 2 & 2 & 31 \\
\hline & $\%$ & 29.0 & 32.3 & 25.8 & 6.5 & 6.5 & 100.0 \\
\hline \multirow{2}{*}{ Kültür } & Sayı & 0 & 23 & 27 & 1 & 0 & 51 \\
\hline & $\%$ & 0.0 & 45.1 & 52.9 & 2.0 & 0.0 & 100.0 \\
\hline \multirow{2}{*}{ Melez } & Say1 & 0 & 38 & 41 & 7 & 5 & 91 \\
\hline & $\%$ & 0.0 & 41.8 & 45.1 & 7.7 & 5.5 & 100.0 \\
\hline \multirow{2}{*}{ Kültür+melez } & Say1 & 0 & 18 & 42 & 0 & 9 & 69 \\
\hline & $\%$ & 0.0 & 26.1 & 60.9 & 0.0 & 13.0 & 100.0 \\
\hline \multirow{2}{*}{ Yerli+melez } & Say1 & 15 & 18 & 16 & 7 & 2 & 58 \\
\hline & $\%$ & 25.9 & 31.0 & 27.6 & 12.1 & 3.4 & 100.0 \\
\hline \multirow{2}{*}{ Yerli+kültür+melez } & Say1 & 6 & 14 & 22 & 2 & 4 & 48 \\
\hline & $\%$ & 12.5 & 29.2 & 45.8 & 4.2 & 8.3 & 100.0 \\
\hline \multirow{2}{*}{ Toplam } & Say1 & 30 & 121 & 156 & 19 & 22 & 348 \\
\hline & $\%$ & 8.6 & 34.8 & 44.8 & 5.5 & 6.3 & 100.0 \\
\hline
\end{tabular}


Çizelge 6. İşletmelerin urk tercihinin besicilikten memnuniyete göre değiş̧imi.

Table 6. The change of the breed preference of the farms according to the satisfaction with the fattening.

\begin{tabular}{|c|c|c|c|c|c|c|c|c|c|c|c|c|c|c|}
\hline \multirow[b]{2}{*}{ Besicilikten memnuniyet } & & \multicolumn{6}{|c|}{ Mevcut lrk* } & \multirow[b]{2}{*}{ Toplam } & \multicolumn{5}{|c|}{ Irk tercihi* } & \multirow[b]{2}{*}{ Toplam } \\
\hline & & Yerli & Kültür & Melez & Melez+kültür & Melez+yerli & Melez+yerli+kültür & & Yerli & Melez & Kültür & Melez+yerli & Kültür+melez/yerli & \\
\hline \multirow[b]{2}{*}{ Evet } & Say1 & 17 & 29 & 63 & 49 & 45 & 34 & 237 & 23 & 69 & 110 & 10 & 17 & 229 \\
\hline & $\%$ & 7.2 & 12.2 & 26.6 & 20.7 & 19.0 & 14.3 & 100.0 & 10.0 & 30.1 & 48.0 & 4.4 & 7.4 & 100.0 \\
\hline \multirow{2}{*}{ Hayır } & Say1 & 20 & 22 & 31 & 23 & 14 & 16 & 126 & 7 & 52 & 46 & 9 & 5 & 119 \\
\hline & $\%$ & 15.9 & 17.5 & 24.6 & 18.3 & 11.1 & 12.7 & 100.0 & 5.9 & 43.7 & 38.7 & 7.6 & 4.2 & 100.0 \\
\hline \multirow{2}{*}{ Toplam } & Say1 & 37 & 51 & 94 & 72 & 59 & 50 & 363 & 30 & 121 & 156 & 19 & 22 & 348 \\
\hline & $\%$ & 10.2 & 14.0 & 25.9 & 19.8 & 16.3 & 13.8 & 100.0 & 8.6 & 34.8 & 44.8 & 5.5 & 6.3 & 100.0 \\
\hline
\end{tabular}

Çizelge 7. İşletmelerin ırk tercihinin besiciliği sürdürmeye göre değişimi.

Table 7. The change of the breed preference of the farms according to the continuation of fattening.

\begin{tabular}{|c|c|c|c|c|c|c|c|c|c|c|c|c|c|c|}
\hline \multirow[b]{2}{*}{ Besiciliği sürdürme } & & \multicolumn{6}{|c|}{ Mevcut 1rk* } & \multirow[b]{2}{*}{ Toplam } & \multicolumn{5}{|c|}{ Irk tercihi } & \multirow[b]{2}{*}{ Toplam } \\
\hline & & Yerli & Kültür & Melez & Melez+kültür & Melez+yerli & Melez+yerli+kültür & & Yerli & Melez & Külttür & Melez+yerli & Kültür+melez/yerli & \\
\hline \multirow{2}{*}{ Evet } & Say1 & 30 & 37 & 83 & 55 & 53 & 45 & 303 & 25 & 102 & 130 & 17 & 18 & 292 \\
\hline & $\%$ & 9.9 & 12.2 & 27.4 & 18.2 & 17.5 & 14.9 & 100.0 & 8.6 & 34.9 & 44.5 & 5.8 & 6.2 & 100.0 \\
\hline \multirow{2}{*}{ Hayır } & Sayl & 7 & 14 & 10 & 17 & 6 & 4 & 58 & 4 & 20 & 25 & 2 & 4 & 55 \\
\hline & $\%$ & 12.1 & 24.1 & 17.2 & 29.3 & 10.3 & 6.9 & 100.0 & 7.3 & 36.4 & 45.5 & 3.6 & 7.3 & 100.0 \\
\hline \multirow{2}{*}{ Toplam } & Say1 & 37 & 51 & 93 & 72 & 59 & 49 & 361 & 29 & 122 & 155 & 19 & 22 & 347 \\
\hline & $\%$ & 10.2 & 14.1 & 25.8 & 19.9 & 16.3 & 13.6 & 100.0 & 8.4 & 35.2 & 44.7 & 5.5 & 6.3 & 100.0 \\
\hline
\end{tabular}

Çizelge 8. İşletmelerin ırk tercihinin besiciliği sürdürme nedenlerine göre değişimi.

Table 8. Change in breeding preference of farms according to the reasons for maintaining fattening.

\begin{tabular}{|c|c|c|c|c|c|c|c|c|c|c|c|c|c|c|}
\hline \multirow{2}{*}{$\begin{array}{l}\text { Besiciliği sürdürme } \\
\text { nedeni }\end{array}$} & & \multicolumn{6}{|c|}{ Mevcut 1rk } & \multirow[b]{2}{*}{ Toplam } & \multicolumn{5}{|c|}{ Irk tercihi** } & \multirow[b]{2}{*}{ Toplam } \\
\hline & & Yerli & Kültür & Melez & Melez+külttür & Melez+yerli & Melez+yerli+kültür & & Yerli & Melez & Kültür & Melez+yerli & Kültür+melez/yerli & \\
\hline \multirow{2}{*}{ Karlı } & Sayı & 1 & 10 & 23 & 14 & 13 & 9 & 70 & 5 & 13 & 40 & 5 & 5 & 68 \\
\hline & $\%$ & 1.4 & 14.3 & 32.9 & 20.0 & 18.6 & 12.9 & 100.0 & 7.4 & 19.1 & 58.8 & 7.4 & 7.4 & 100.0 \\
\hline \multirow{2}{*}{ Bana yetiyor } & Say 1 & 11 & 10 & 19 & 12 & 8 & 20 & 80 & 4 & 19 & 43 & 5 & 6 & 77 \\
\hline & $\%$ & 13.8 & 12.5 & 23.8 & 15.0 & 10.0 & 25.0 & 100.0 & 5.2 & 24.7 & 55.8 & 6.5 & 7.8 & 100.0 \\
\hline \multirow{2}{*}{ Başka iş yok } & Sayı & 14 & 15 & 32 & 23 & 25 & 14 & 123 & 15 & 56 & 33 & 6 & 7 & 117 \\
\hline & $\%$ & 11.4 & 12.2 & 26.0 & 18.7 & 20.3 & 11.4 & 100.0 & 12.8 & 47.9 & 28.2 & 5.1 & 6.0 & 100.0 \\
\hline \multirow{2}{*}{ Sevmek } & Sayı & 4 & 2 & 9 & 6 & 7 & 2 & 30 & 1 & 14 & 14 & 1 & 0 & 30 \\
\hline & $\%$ & 13.3 & 6.7 & 30.0 & 20.0 & 23.3 & 6.7 & 100.0 & 3.3 & 46.7 & 46.7 & 3.3 & 0.0 & 100.0 \\
\hline \multirow{2}{*}{ Toplam } & Say1 & 30 & 37 & 83 & 55 & 53 & 45 & 303 & 25 & 102 & 130 & 17 & 18 & 292 \\
\hline & $\%$ & 9.9 & 12.2 & 27.4 & 18.2 & 17.5 & 14.9 & 100.0 & 8.6 & 34.9 & 44.5 & 5.8 & 6.2 & 100.0 \\
\hline
\end{tabular}


Çizelge 9. İşletmelerin ırk tercihinin işletmecilerin besicilik yapma nedenine göre değişimi.

Table 9. The change of the breed preference of the farms according to the reason of the breeders.

\begin{tabular}{|c|c|c|c|c|c|c|c|c|c|c|c|c|c|c|}
\hline \multirow[b]{2}{*}{ Besicilik yapma nedeni } & & \multicolumn{6}{|c|}{ Mevcut Irk** } & \multirow[b]{2}{*}{ Toplam } & \multicolumn{5}{|c|}{ Irk tercihi* } & \multirow[b]{2}{*}{ Toplam } \\
\hline & & Yerli & Kültür & Melez & Melez+kültür & Melez+yerli & Melez+yerli+kültür & & Yerli & Melez & Kültür & Melez+yerli & Kültürr+melez/yerli & \\
\hline \multirow[t]{2}{*}{ Baba mesleği } & Say1 & 21 & 18 & 31 & 28 & 27 & 17 & 142 & 15 & 44 & 63 & 4 & 12 & 138 \\
\hline & $\%$ & 14.8 & 12.7 & 21.8 & 19.7 & 19.0 & 12.0 & 100.0 & 10.9 & 31.9 & 45.7 & 2.9 & 8.7 & 100.0 \\
\hline \multirow[t]{2}{*}{ Sevmek } & Sayı & 3 & 14 & 15 & 10 & 10 & 6 & 58 & 5 & 22 & 26 & 1 & 1 & 55 \\
\hline & $\%$ & 5.2 & 24.1 & 25.9 & 17.2 & 17.2 & 10.3 & 100.0 & 9.1 & 40.0 & 47.3 & 1.8 & 1.8 & 100.0 \\
\hline \multirow[t]{2}{*}{ Başka iş yok } & Sayı & 8 & 10 & 21 & 19 & 10 & 19 & 87 & 6 & 33 & 33 & 5 & 6 & 83 \\
\hline & $\%$ & 9.2 & 11.5 & 24.1 & 21.8 & 11.5 & 21.8 & 100.0 & 7.2 & 39.8 & 39.8 & 6.0 & 7.2 & 100.0 \\
\hline \multirow[t]{2}{*}{ Baba mesleği+sevmek } & Sayı & 4 & 8 & 4 & 6 & 2 & 4 & 28 & 3 & 11 & 11 & 1 & 1 & 27 \\
\hline & $\%$ & 14.3 & 28.6 & 14.3 & 21.4 & 7.1 & 14.3 & 100.0 & 11.1 & 40.7 & 40.7 & 3.7 & 3.7 & 100.0 \\
\hline \multirow{2}{*}{$\begin{array}{l}\text { Baba mesleği+başka iş } \\
\text { yok }\end{array}$} & Say1 & 1 & 2 & 22 & 8 & 10 & 4 & 47 & 1 & 10 & 23 & 8 & 2 & 44 \\
\hline & $\%$ & 2.1 & 4.3 & 46.8 & 17.0 & 21.3 & 8.5 & 100.0 & 2.3 & 22.7 & 52.3 & 18.2 & 4.5 & 100.0 \\
\hline \multirow{2}{*}{ Toplam } & Say1 & 37 & 52 & 93 & 71 & 59 & 50 & 362 & 30 & 120 & 156 & 19 & 22 & 347 \\
\hline & $\%$ & 10.2 & 14.4 & 25.7 & 19.6 & 16.3 & 13.8 & 100.0 & 8.6 & 34.6 & 45.0 & 5.5 & 6.3 & 100.0 \\
\hline
\end{tabular}

** $\mathrm{p}<0.01,{ }^{*} \mathrm{p}<0.05$

Çizelge 10. İşletmelerin ırk tercihinin besi programına göre değişimi.

Table 10. The change of the breed preference of the farms according to the fattening program.

\begin{tabular}{|c|c|c|c|c|c|c|c|c|c|c|c|c|c|c|}
\hline \multirow[b]{2}{*}{ Besi program 1} & & \multicolumn{6}{|c|}{ Mevcut 1rk** } & \multirow[b]{2}{*}{ Toplam } & \multicolumn{5}{|c|}{ Irk tercihi*** } & \multirow[b]{2}{*}{ Toplam } \\
\hline & & Yerli & Kültür & Melez & Melez+kültür & Melez+yerli & Melez+yerli+kültür & & Yerli & Melez & Kültür & Melez+yerli & Kültür+melez/yerli & \\
\hline \multirow{2}{*}{ Mera } & Say1 & 2 & 7 & 5 & 4 & 10 & 0 & 28 & 3 & 16 & 9 & 0 & 0 & 28 \\
\hline & $\%$ & 7.1 & 25.0 & 17.9 & 14.3 & 35.7 & 0.0 & 100.0 & 10.7 & 57.1 & 32.1 & 0.0 & 0.0 & 100.0 \\
\hline \multirow[t]{2}{*}{ Mera ve kesif yem } & Sayı & 7 & 26 & 56 & 31 & 18 & 36 & 174 & 14 & 53 & 88 & 4 & 12 & 171 \\
\hline & $\%$ & 4.0 & 14.9 & 32.2 & 17.8 & 10.3 & 20.7 & 100.0 & 8.2 & 31.0 & 51.5 & 2.3 & 7.0 & 100.0 \\
\hline \multirow{2}{*}{$\begin{array}{l}\text { Kesif }+ \text { kaba yem } \\
\text { (ahır besisi) }\end{array}$} & Sayı & 15 & 11 & 28 & 27 & 22 & 9 & 112 & 9 & 41 & 41 & 11 & 10 & 112 \\
\hline & $\%$ & 13.4 & 9.8 & 25.0 & 24.1 & 19.6 & 8.0 & 100.0 & 8.0 & 36.6 & 36.6 & 9.8 & 8.9 & 100.0 \\
\hline \multirow{2}{*}{ Toplam } & Say1 & 24 & 44 & 89 & 62 & 50 & 45 & 314 & 26 & 110 & 138 & 15 & 22 & 311 \\
\hline & $\%$ & 7.6 & 14.0 & 28.3 & 19.7 & 15.9 & 14.3 & 100.0 & 8.4 & 35.4 & 44.4 & 4.8 & 7.1 & 100.0 \\
\hline
\end{tabular}




\section{Kaynaklar}

Bakır G (2002) Van ilindeki özel süt sı ğırcılığı ișletmelerinde tercih edilen kültür ırkları. Yüzüncü Yıl Üniversitesi Tarım Bilimleri Dergisi 122: 11-20.

Bakır G, Han Y (2009) Besi uygulamaları ve ırk tercihlerine yetistirilen ırkın etkisi. Yüzüncü Yıl Üniversitesi Fen Bilimleri Enstitüsü Dergisi 14(1): 7-14.

Bakır G, Kibar M (2019) Muş ilinde süt sığırcılığı işletmelerinde ırk tercihi ve etkileyen faktörler. Mediterrian Agricultural Sciences 32(2): 257-262.

Bakır G, Ören MY (2020) Süt sığırcılığı işletmelerinde ırk tercihi ve etkileyen faktörler: Siirt ili örneği. Kahramanmaraş Sütçü İmam Üniversitesi Tarım ve Doğa Dergisi 23(5): 1393-1405.

Cochran WG (1977) Sampling Techniques (3rd Edition). John Wiley\&Sons. New York. https://www. academia.edu/29684662/ Cochran_1977_Sampling_ Techniques Third_Edition. pdf. Erişism 14 Ocak 2019.

Daş A, İnci H, Karakaya E, Şengül AY (2014) Bingöl İli damızlık sığır yetiştiricileri birliğine bağlı sığırcılık işletmelerinin mevcut durumu. Türk Tarım ve Doğa Bilimleri Dergisi 1(3): 421-429.

Düzgüneş O, Kesici T, Gürbüz F (1983) İstatistik metodları I. Ankara Üniversitesi Ziraat Fakültesi Yay. 229, Ankara.

Güler O, Aydın R, Yanar M, Diler A, Koçyiğit R, Avcı M (2016) Erzurum İli hınıs ilçesi sığırcılık işletmelerinin sosyo-ekonomik yapısı. Alınteri Zirai Bilimler Dergisi 30(1): 27-37.

Han Y, Bakır G (2009) Özel Besi sığırcılığı işletmelerinde ırk tercihleri ve besi uygulamaları. Atatürk Üniversitesi Ziraat Fakültesi Dergisi 40(2): 35-41.
Kaylan V, Yılmaz İ, Yanar M (2019) Iğdır ili büyükbaş hayvan yetiştiricilerinin rrk tercihleri ve et ithaline bakışları. Journal of Agriculture 2(1): 22-29.

Şeker İ, Tasalı H, Güler H (2012) Muş İlinde sığır yetiştiriciliği yapılan işletmelerin yapısal özellikleri. Fırat Üniversitesi Sağlık Bilimleri Veteriner Dergisi 26(1): 9-16.

Tugay A (2003) Giresun yöresindeki süt sı̆̆ırcılı̆̆ı işletmelerinin genel değerlendirilmesi. Yüksek lisans tezi, Yüzüncü Yıl Üniversitesi Fen Bilimleri Enstitüsü, Van.

Tugay A, Bakır G (2006) Giresun yöresindeki özel süt sığırcılığı işletmelerinin ırk tercihleri ve barınakların yapısal durumu. Atatürk Üniversitesi Ziraat Fakültesi Dergisi 37(1): 39-47.

Yamane T (2006) Temel Örnekleme Yöntemleri. (Çeviri: Esin A, Bakır MA, Aydın C, Güzbüzsel E.) Literatür Yayınları: 53, İstanbul, 411.

Yazıcıoğlu Y, Erdoğan S (2014) SPSS uygulamalı bilimsel araştırma yöntemleri. Detay Yayıncılık.

Yılmaz İ, Dağıstan E, Koç B, Özel R (2003) Hatay ilinde projeli ve projesiz süt sığırcılığı yapan işletmelerin süt sığırcılığı üretim faaliyetlerinin ve faktör verimliliklerinin analizi. Mediterranean Agricultural Sciences 16(2): 169178.

Yılmaz İ (2005) Erzurum ilinde farklı kaynaklardan getirilen kültür ırk1 sığırlarla yapılan yetiştiriciliğin analizi. Doktora Tezi, Atatürk Üniversitesi Fen Bilimleri Enstitüsü, Erzurum. 